\title{
Pelilinan Efektif Memperpanjang Masa Simpan Buah Jambu Biji (Psidium guajava L.) 'Kristal'
}

\author{
Waxing Effectively Prolonged Fruit Shelflife \\ of 'Kristal' Guava (Psidium guajava L.)
}

Slamet Susanto $^{1 *}$, Delys Inkorisa ${ }^{2}$ dan Dadang Hermansyah ${ }^{2}$

Diterima 25 Oktober 2017/Disetujui 08 Januari 2018

\begin{abstract}
'Kristal' guava fruit can easily be deteriorated during storage. The objective of this experiment was to study the effect of the waxing on the shelflife and quality of the 'Kristal' guava fruit. Experiment was conducted at the Postharvest Laboratory of Departemen of Agronomy and Horticulture, Faculty of Agriculture, Bogor Agricultural University from February to May 2016. The experiment was designed using completely randomized design (CRD) with single factor consisted of 5 treatments, i.e., $0 \%$ of beewax (control), 2\% of beewax, $4 \%$ of beewax, $6 \%$ of beewax and $8 \%$ of beeswax. The results showed that beewax coating suppressed weight loss and softness of fruit compared to the control fruit during storage period. Beewax coating did not significantly affect chemical quality such as soluble solids content, titratable acidity and vitamin $C$. The beeswax coating with $2 \%$ and $4 \%$ were able to extend shelflife of 'Kristal' guava fruit 9 days longer as compared to the control.
\end{abstract}

Keywords: 'Kristal', performance, quality, waxing, weight loss

\begin{abstract}
ABSTRAK
Buah jambu 'Kristal' dapat dengan mudah rusak selama penyimpanan. Tujuan percobaan ini yaitu mempelajari pengaruh pelilinan terhadap daya simpan dan kualitas buah jambu 'Kristal'. Percobaan dilakukan di Laboratorium Pascapanen, Departemen Agronomi dan Hortikultura, Fakultas Pertanian, Institut Pertanian Bogor dari bulan Februari sampai Mei 2016. Percobaan dirancang menggunakan rancangan acak lengkap (RAL) dengan faktor tunggal terdiri atas 5 perlakuan, yaitu 0\% dari lilin lebah (kontrol), 2\% dari lilin lebah, 4\% lilin lebah, 6\% lilin lebah dan $8 \%$ lilin lebah. Hasil penelitian menunjukkan bahwa pelapisan lilin lebah menekan susut bobot dan kelunakan buah dibandingkan dengan kontrol selama masa penyimpanan. Pelapisan lilin lebah tidak secara nyata mempengaruhi kualitas kimia buah seperti kandungan padatan terlarut, keasaman titrasi dan vitamin C. Pelapisan lilin lebah dengan konsentrasi $2 \%$ dan $4 \%$ mampu memperpanjang masa simpan buah jambu 'Kristal' 9 hari lebih lama dibandingkan dengan kontrol.
\end{abstract}

Kata Kunci: kualitas, 'Kristal', pelilinan, penampilan, susut bobot

${ }^{1}$ Departemen Agronomi dan Hortikultura, Fakultas Pertanian, Institut Pertanian Bogor

${ }^{2}$ Mahasiswa Pascasarjana, Departemen Agronomi dan Hortikultura, Fakultas Pertanian, Institut Pertanian Bogor

Jl. Meranti, Kampus IPB Darmaga, Bogor 16680, Indonesia

Email: slmtsanto@gmail.com (*Penulis korespondensi) 


\section{PENDAHULUAN}

Jambu biji (Psidium guajava L.) merupakan komoditas hortikultura yang banyak diminati oleh masyarakat Indonesia karena rasa dan aroma jambu biji yang enak, kandungan vitamin $\mathrm{C}$ tinggi dan memiliki banyak manfaat untuk kesehatan. Produksi jambu biji di Indonesia meningkat dari 181644 ton pada tahun 2013 menjadi 206985 ton pada tahun 2016 (BPS, 2018), seiring dengan permintaan konsumen yang terus meningkat. Konsumsi jambu biji tahun 2014 sebesar 0.313 $\mathrm{kg}$ meningkat menjadi 0.728 per kapita per tahun pada 2017 (Kementan, 2018).

Bentuk, ukuran, rasa, dan warna daging buah jambu biji bervariasi tergantung varietasnya. Umumnya buah jambu biji berbentuk bulat atau agak lonjong (Paull dan Duarte, 2012). Salah satu kultivar jambu biji yang saat ini disukai oleh masyarakat adalah jambu biji 'Kristal'. Keunggulan buah jambu 'Kristal' ialah tidak berbiji atau memiliki biji sedikit sekali, kurang dari 3\% dari bagian buah dengan tekstur dagingnya renyah dibandingkan varietas lainnya dan rasa manis segar (Ditbenih, 2012).

Kualitas buah jambu biji sangat dipengaruhi oleh tingkat kemasakan buah dan metode penyimpanan yang akan berpengaruh terhadap rasa, penampakan, aroma dan nutrisi buah. Jambu biji dengan kualitas yang baik akan didapatkan apabila buah dipetik pada tingkat kematangan yang cukup. Buah jambu biji yang dipetik pada saat belum matang akan memiliki rasa yang masih sepat, dengan daging buah masih keras dan kandungan jus yang rendah. Paull dan Duarte (2012) menyebutkan bahwa selama pematangan buah mengalami perubahan nyata dalam warna dan tekstur, yang menunjukkan bahwa terjadi perubahan-perubahan fisiologis di dalamnya, termasuk perubahan pada karbohidrat, asam organik, protein, asam amino dan komponen lain dapat mempengaruhi cita rasa pada buah. Selanjutnya masa penyimpanan buah dapat menjadi masalah dalam kegiatan pascapanen karena buah termasuk komoditas yang mudah rusak. Widodo et al. (2012) melaporkan bahwa buah jambu biji memiliki daya simpan antara 2-7 hari. Oleh karena itu perlu penanganan pascapanen yang baik agar mempunyai masa simpan yang lebih lama.
Salah satu metode yang dapat digunakan untuk memperpanjang masa simpan buah adalah pelapisan. Lilin umumnya digunakan sebagai bahan pelapis buah dan sayuran untuk menekan kehilangan air selama penyimpanan dan untuk memperpanjang umur simpan. Buah dan sayuran pada umumnya memiliki lapisan lilin alami yang membantu menahan air, karena produk hortikultura mengandung $80 \%$ - 90\% air. Pelapisan lilin pada produk hortikultura untuk menggantikan lapisan lilin alami yang hilang selama pencucian. Pelapisan lilin jika diaplikasikan dengan konsentrasi yang tepat mampu mempertahankan kualitas fisik dan kimia pada berbagai buah-buahan (Li et al., 2018; Mendeita et al., 2017; Shahid dan Abbasi, 2011; Shetty et al., 2018). Selain itu pelapisan lilin juga dapat membantu menghambat pertumbuhan cendawan, melindungi dari luka memar, dan meningkatkan penampilan (Machado et al., 2012; Pascall dan Lin, 2013, Vasquez-Celestino et al., 2016).

Lilin lebah termasuk pelapis edibel yang banyak digunakan sebagai bahan pelapis. Menurut Pavlath dan Orts (2009), pelapis edibel merupakan semua jenis bahan yang digunakan sebagai pelapis atau pembungkus berbagai makanan yang bertujuan untuk memperpanjang umur simpan produk, yang dapat dikonsumsi bersama-sama dengan makanan baik dengan maupun tanpa pembuangan lapisan tersebut.

Tujuan utama pelapisan lilin pada produk hortikultura ialah menekan respirasi dan transpirasi agar buah tidak cepat layu, berkerut, dan busuk. Penelitian ini bertujuan mempelajari pengaruh pelapisan lilin lebah terhadap masa simpan dan kualitas buah jambu 'Kristal'.

\section{BAHAN DAN METODE}

Percobaan dilaksanakan pada bulan Februari 2016 sampai bulan Mei 2016. Penelitian ini dilaksanakan di Laboratorium Pascapanen Departemen Agronomi dan Hortikultura, Fakultas Pertanian, IPB. Bahan yang digunakan dalam percobaan ini adalah buah jambu 'Kristal' yang dipanen dari kebun petani di Desa Batuhalang, Kecamatan Dramaga, Kabupaten Bogor. Buah jambu 'Kristal' berasal dari pohon berumur 4 tahun 
dan memiliki tingkat kematangan seragam berdasarkan kriteria panen petani yaitu buah berumur 116-120 hari dan berwarna hijau kekuningan.

Pelaksanaan percobaan diawali dengan pembuatan larutan stok emulsi lilin $12 \%$. Proses pembuatan emulsi lilin lebah yaitu mencampurkan lilin lebah sebanyak $120 \mathrm{~g}$ yang sudah mencair dengan asam oleat sebanyak $20 \mathrm{ml}$, dan aquades $820 \mathrm{ml}$ dengan trietanolamin $40 \mathrm{ml}$ pada suhu $90-95{ }^{\circ} \mathrm{C}$, masing-masing dalam panci yang berbeda. Kemudian larutan pada kedua panci tersebut dicampur sambil diaduk hingga mencapai suhu ruang. Larutan emulsi lilin lebah $12 \%$ kemudian diencerkan sesuai konsentrasi yang digunakan dalam perlakuan.

Tahap selanjutnya yaitu melakukan pencucian dan sortasi buah yang sudah dipanen. Pelapisan buah dengan lilin lebah dilakukan dengan mencelupkan buah ke dalam masing-masing larutan emulsi sesuai perlakuan selama 30 detik, kemudian dikeringanginkan.

Percobaan dilakukan dalam rancangan acak lengkap (RAL) faktor tunggal pelilinan yang terdiri atas 5 perlakuan yaitu: $\mathrm{P} 0=$ tanpa lapisan, $\mathrm{P} 1=$ lapisan lilin lebah $2 \%, \mathrm{P} 2=$ lapisan lilin lebah 4\%, P3 = lapisan lilin lebah $6 \%$ dan $\mathrm{P} 4=$ lapisan lilin lebah $8 \%$. Setiap perlakuan terdiri atas 3 ulangan sehingga terdapat 15 satuan percobaan. Setiap satuan percobaan memerlukan 20 butir buah jambu 'Kristal' (16 butir buah untuk pengamatan destruktif dan 4 butir buah untuk pengamatan non-destruktif) sehingga total dibutuhkan 300 butir buah jambu 'Kristal'.

Pengamatan dilakukan setiap 3 hari sekali, dimulai awal penyimpanan hingga akhir penyimpanan. Pengamatan meliputi susut bobot yang dilakukan secara nondestruktif dengan mengukur perubahan bobot setiap melakukan pengamatan, dan pengamatan destruktif yang meliputi padatan terlarut total, kekerasan, total asam tertitrasi, vitamin C (AOAC, 1995). Selain itu dilakukan uji organoleptik rasa setiap 6 hari dengan menggunakan 15 panelis tetap. Untuk uji organoleptik rasa digunakan buah yang sama dengan yang digunakan untuk uji kualitas. Uji organoleptik digunakan untuk menentukan batas tingkat penerimaan konsumen.

Data hasil pengamatan dianalisis dengan sidik ragam menggunakan software SAS versi 9.1 dan MS Excel 2010. Hasil analisis sidik ragam yang menunjukkan bahwa perlakuan memberikan pengaruh nyata terhadap peubah yang diamati, dilakukan uji beda nilai tengah dengan Duncan Multiple Range Test (DMRT) pada taraf $\alpha=5 \%$.

\section{HASIL DAN PEMBAHASAN}

Secara keseluruhan buah mengalami peningkatan susut bobot selama penyimpanan. Perlakuan pelilinan mulai memberikan pengaruh terhadap penekanan susut bobot buah jambu 'Kristal' pada pengamatan hari ketiga dan berpengaruh nyata pada pengamatan mulai hari ke enam (Tabel 1). Penekanan terhadap susut bobot akibat perlakuan pelilinan juga dilaporkan pada grapefruit (Abdel-Kader et al., 2011), jeruk manis (Shahid dan Abbasi, 2011), dan tangerine (Boonyakiat et al., 2012; Hassan et al., 2014). Peningkatan susut bobot disebabkan oleh hilangnya air akibat proses respirasi dan transpirasi yang terjadi selama penyimpanan (Wills et al., 2007).

Tabel 1. Pengaruh perlakuan pelapisan lilin terhadap susut bobot buah jambu 'Kristal'

\begin{tabular}{cccccccc}
\hline \multirow{2}{*}{ Pelilinan } & \multicolumn{7}{c}{ Susut Bobot Buah (\%) Pada Hari Ke- } \\
\cline { 2 - 7 } & 3 & 6 & 9 & 12 & 15 & 18 \\
\hline $0 \%$ & 5.21 & $11.77 \mathrm{a}$ & $18.48 \mathrm{a}$ & - & - & - \\
$2 \%$ & 4.62 & $9.88 \mathrm{~b}$ & $13.32 \mathrm{~b}$ & 15.32 & 18.29 & 19.22 \\
$4 \%$ & 4.53 & $9.52 \mathrm{~b}$ & $13.11 \mathrm{~b}$ & 16.10 & 18.11 & 18.56 \\
$6 \%$ & 4.36 & $8.98 \mathrm{~b}$ & $12.98 \mathrm{~b}$ & 16.02 & - & - \\
$8 \%$ & 4.83 & $9.72 \mathrm{~b}$ & $12.83 \mathrm{~b}$ & 15.38 & - & - \\
\hline
\end{tabular}

Keterangan: - = buah busuk. Angka yang diikuti huruf berbeda dalam satu kolom menunjukkan beda nyata pada uji DMRT $5 \%$. 
Buah jambu 'Kristal' tanpa perlakuan (kontrol) hanya memiliki masa simpan hingga 9 hari. Hal ini disebabkan buah sudah memiliki bercak coklat pada kulit buah pada pengamatan setelahnya. Pada perlakuan lilin $2 \%$ dan $4 \%$ buah memiliki umur simpan sampai dengan 18 hari. Selanjutnya pada perlakuan lilin lebah 6\% dan $8 \%$ masa simpan hanya sampai dengan 12 hari, disebabkan buah mulai melunak dan membusuk pada pengamatan setelahnya. Hal ini diduga pelapisan lilin yang terlalu tebal mengakibatkan jaringan buah kekurangan oksigen sehingga terjadi proses fermentasi yang menghasilkan pelunakan jaringan kulit buah. Selain itu pelapisan lilin yang terlalu tebal juga menghambat transpirasi yang mengakibatkan jaringan kulit buah menjadi lembab sehingga buah lebih mudah terserang pathogen dan membusuk. $\mathrm{Di}$ sisi lain perlakuan pelilinan $2 \%$ dan $4 \%$ dapat secara efektif menghambat laju transpirasi dan respirasi tanpa menimbulkan kebusukan sehingga mampu memperpanjang masa simpan buah lebih lama dibandingkan dengan perlakuan pelilinan $6 \%$ dan $8 \%$ serta kontrol.

Kehilangan bobot dan kadar air buah terutama disebabkan oleh transpirasi buah, di mana air bergerak keluar dan mengakibatkan kulit menjadi layu dan keriput (Wills et al., 2007). Pada jeruk manis dan mandarin, kehilangan air sebesar 5-6\% mengakibatkan perubahan dalam penampilan buah dan kekerasan kulit buah (Fikrinda et al., 2015). Pelilinan efektif digunakan untuk menekan kehilangan air dari buah, mencegah pengerutan, dan mempertahankan kualitas buah (Hassan et al., 2014; Shetty et al., 2018; Vázquez-Celestino et al., 2016).

\section{Kelunakan Buah}

Buah mengalami proses pelunakan jaringan selama penyimpanan. Tabel 2 menunjukkan perlakuan pelapisan lilin mampu menekan kelunakan buah pada pengamatan mulai hari ketiga. Pada pengamatan hari ke-9, pada buah kontrol tidak saja menunjukkan tingkat kelunakan yang lebih tinggi tetapi juga keriput, dan pada pengamatan hari ke-12 buah mulai nampak membusuk. Buah dengan pelapisan lilin 6\% dan 8\% menunjukkan penampilan yang baik sampai dengan minggu ke-9, tetapi kemudian menunjukkan tingkat kelunakan yang tinggi pada minggu ke 12 dan mulai membusuk. Hal ini diduga sebagai hasil proses fermentasi yang terjadi akibat jaringan kulit buah kekurangan oksigen karena pelapisan yang terlalu tebal.

Pada perlakuan 2\% dan $4 \%$ dapat memperpanjang masa simpan buah sampai dengan hari ke-18. Tidak ada perbedaan yang nyata antara nilai kelunakan buah pada perlakuan lilin 2\% dan 4\% (Tabel 2). Pelapisan dengan konsentrasi yang sesuai mampu mempertahankan kekerasan buah selama periode penyimpanan, seperti yang dilaporkan oleh Shahid dan Abbasi (2011) pada jeruk manis, Vasquaz-Celestino (2016) pada mangga, dan Aji (2017) pada pamelo.

Secara keseluruhan, terjadi proses pelunakan dengan bertambahnya waktu penyimpanan. Pada kulit buah terjadi perubahan protopektin yang tidak larut air berubah menjadi komponen yang larut air yang menyebabkan kekerasan kulit buah menjadi menurun dan buah menjadi lunak (Wills et al., 2007). Pektin dan hemiselulosa mengalami depolimerisasi yang berpengaruh terhadap pelunakan dan disintegrasi dinding sel (Vicente et al., 2007).

Tabel 2. Pengaruh perlakuan pelapisan lilin terhadap kelunakan buah jambu 'Kristal'

\begin{tabular}{cccccccc}
\hline \multirow{2}{*}{ Pelilinan } & \multicolumn{7}{c}{ Nilai Kelunakan $(\mathrm{mm} / 50 \mathrm{~g} / 10$ detik) Pada Hari Ke- } \\
\cline { 2 - 8 } & 0 & 3 & 6 & 9 & 12 & 15 & 18 \\
\hline $0 \%$ & 33.81 & $37.17 \mathrm{a}$ & $42.30 \mathrm{a}$ & 43.62 & - & - & - \\
$2 \%$ & 33.00 & $34.97 \mathrm{ab}$ & $39.02 \mathrm{~b}$ & 42.22 & $45.14 \mathrm{~b}$ & 46.65 & 47.17 \\
$4 \%$ & 34.00 & $36.86 \mathrm{ab}$ & $37.80 \mathrm{~b}$ & 42.25 & $44.07 \mathrm{~b}$ & 45.22 & 46.58 \\
$6 \%$ & 32.37 & $36.22 \mathrm{ab}$ & $38.58 \mathrm{~b}$ & 41.01 & $47.32 \mathrm{a}$ & - & - \\
$8 \%$ & 30.61 & $34.28 \mathrm{~b}$ & $37.80 \mathrm{~b}$ & 40.76 & $46.86 \mathrm{a}$ & - & - \\
\hline
\end{tabular}

Keterangan: - = buah busuk. Angka yang diikuti huruf berbeda dalam satu kolom menunjukkan beda nyata pada uji DMRT $5 \%$. 


\section{Padatan Terlarut Total}

Tabel 3 menunjukkan semua perlakuan lapisan lilin tidak memberikan pengaruh yang nyata terhadap kandungan PTT buah jambu 'Kristal' selama penyimpanan. Nilai PTT berkisar antara 6.86-7.34 ${ }^{\circ}$ Brix pada pengamatan hari ke-0 dan meningkat menjadi 7.53-7.85 ${ }^{\circ}$ Brix pada pengamatan hari ke-9, selanjutnya tidak ada perubahan yang berarti sampai dengan pengamatan hari ke-18. Dhyan et al. (2014) melaporkan bahwa nilai PTT buah jambu biji meningkat selama penyimpanan. Peningkatan PTT selama penyimpanan juga dilaporkan oleh Piga et al. (1997) pada lemon dan Rodov et al. (2000) pada grapefruit. Peningkatan PTT buah terjadi karena kandungan pati yang tidak larut dalam air berubah menjadi gula sederhana seperti glukosa, fruktosa, dan sukrosa yang dapat larut dalam air (Wills et al., 2007).

\section{Asam Tertitrasi Total}

Asam tertitrasi total (ATT) merupakan jumlah asam yang terkandung di dalam buah. Perlakuan lapisan lilin lebah tidak berpengaruh nyata terhadap kandungan ATT buah. Kandungan ATT buah pada semua perlakuan menurun seiring lamanya waktu penyimpanan. Nilai ATT berkisar antara $0.29-0.31 \%$ pada awal penyimpanan dan turun menjadi 0.14$0.15 \%$ pada akhir pengamatan pada hari ke-18 (Tabel 4). Penurunan kandungan ATT yang besar juga terjadi pada pamelo selama penyimpanan (Fikrinda et al., 2015; Sirisomboon dan Lapchareonsuk, 2012).

\section{Kandungan Vitamin C}

Perlakuan pelapisan lilin tidak bepengaruh nyata terhadap kandungan vitamin $\mathrm{C}$ buah setiap waktu pengamatan. Nilai kandungan vitamin $\mathrm{C}$ tertinggi pada buah jambu 'Kristal' yaitu 195.44-198.21 mg/100g pada awal penyimpanan dan turun menjadi 130.94-133.12 mg/100g pada pengamatan hari ke-18 (Gambar 4). Pada penelitian sebelumnya Fitria (2016) melaporkan bahwa kandungan vitamin C buah jambu 'Kristal' sebesar 130.33 $\mathrm{mg} / 100 \mathrm{~g}$ pada saat panen. Perbedaan ini diduga akibat kondisi agroklimat dan umur panen yang berbeda. Taris et al. (2015) melaporkan bahwa pada papaya perbedaan kandungan vitamin $\mathrm{C}$ terjadi akibat umur panen yang berbeda.

Tabel 3. Pengaruh perlakuan pelapisan lilin lebah terhadap kandungan PTT buah jambu 'Kristal'

\begin{tabular}{cccccccc}
\hline \multirow{2}{*}{ Pelilinan } & \multicolumn{7}{c}{ Nilai Padatan Terlarut Total $\left({ }^{\circ}\right.$ Brix $)$ Pada Hari Ke- } \\
\cline { 2 - 8 } & 0 & 3 & 6 & 9 & 12 & 15 & 18 \\
\hline $0 \%$ & 7.14 & 7.38 & 7.17 & 7.53 & - & - & - \\
$2 \%$ & 6.87 & 7.02 & 7.14 & 7.55 & 7.59 & 7.66 & 7.79 \\
$4 \%$ & 6.86 & 7.22 & 7.28 & 7.67 & 7.67 & 7.72 & 7.87 \\
$6 \%$ & 7.14 & 7.79 & 7.58 & 7.85 & 7.83 & - & - \\
$8 \%$ & 7.34 & 7.77 & 7.82 & 7.79 & 7.94 & - & - \\
\hline
\end{tabular}

Keterangan : - = buah busuk.

Tabel 4. Pengaruh perlakuan pelapisan lilin lebah dan pengemasan wrap terhadap kandungan ATT buah jambu 'Kristal'

\begin{tabular}{cccccccc}
\hline \multirow{2}{*}{ Pelilinan } & \multicolumn{7}{c}{ Nilai Asam Tertitrasi Total (\%) Pada Hari Ke- } \\
\cline { 2 - 8 } & 0 & 3 & 6 & 9 & 12 & 15 & 18 \\
\hline $0 \%$ & 0.32 & 0.30 & 0.23 & 0.16 & - & - & - \\
$2 \%$ & 0.31 & 0.29 & 0.23 & 0.17 & 0.14 & 0.14 & 0.14 \\
$4 \%$ & 0.30 & 0.28 & 0.24 & 0.17 & 0.13 & 0.16 & 0.15 \\
$6 \%$ & 0.30 & 0.27 & 0.22 & 0.16 & 0.14 & - & - \\
$8 \%$ & 0.29 & 0.28 & 0.22 & 0.16 & 0.14 & - & - \\
\hline
\end{tabular}




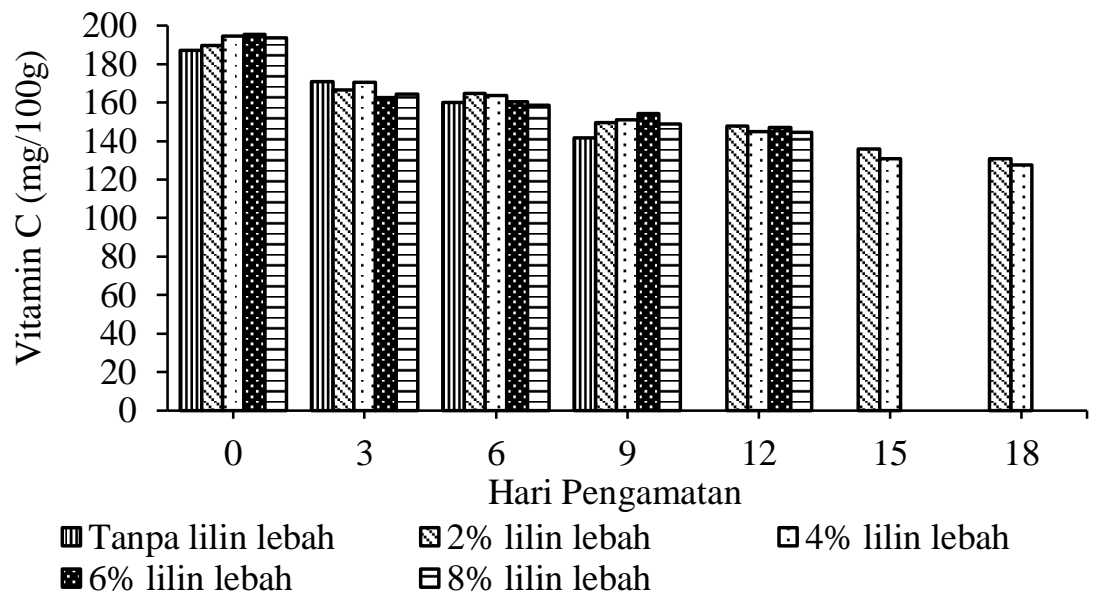

Gambar 4. Kandungan vitamin C buah jambu 'Kristal' pada beberapa perlakuan pelilinan

Secara umum, nilai kandungan vitamin C buah pada perlakuan pelilinan (Gambar 4) masih termasuk tinggi walaupun menurun selama penyimpanan. Kandungan vitamin $\mathrm{C}$ umumnya terus menurun dengan bertambahnya periode penyimpanan karena vitamin $\mathrm{C}$ merupakan senyawa yang tidak stabil dan mudah mengalami degradasi selama penyimpanan. Penurunan kandungan vitamnin C selama penyimpanan juga dilaporkan pada jeruk (Burdurlu et al., 2006).

\section{Uji Organoleptik}

Pengujian organoletik dilakukan untuk mengetahui tanggapan panelis secara subjektif tentang kesukaan atau ketidak-sukaan pada komoditi tertentu. Perlakuan konsentrasi lilin lebah $6 \%$ dan $8 \%$ dapat diuji organoleptik sebanyak 3 kali pengamatan karena buah mengalami kebusukan setelah hari ke-12. Pada perlakuan pelilinan $2 \%$ dan $4 \%$ uji organoleptik dapat dilakukan sebanyak 4 kali sampai dengan hari ke-18 (Gambar 5).

Hasil uji organoleptik menunjukkan bahwa tidak terdapat perbedaan yang nyata antar perlakuan pada periode pengamatan yang sama selama penyimpanan. Tingkat kesukaan panelis berkisar antara 4.1-4.3 pada awal penyimpanan dan menurun menjadi 3.1-3.2 pada akhir penyimpanan pada hari ke-18 untuk perlakuan lilin 2\% dan 4\% (Gambar 5). Skor tingkat kesukaan 3 dianggap skor minimal yang dapat diterima konsumen. Dhyan et al. (2014) menyatakan bahwa semakin lama penyimpanan buah jambu biji akan mengalami kemunduran sehingga akan menghasilkan rasa dan aroma yang tidak dikehendaki.

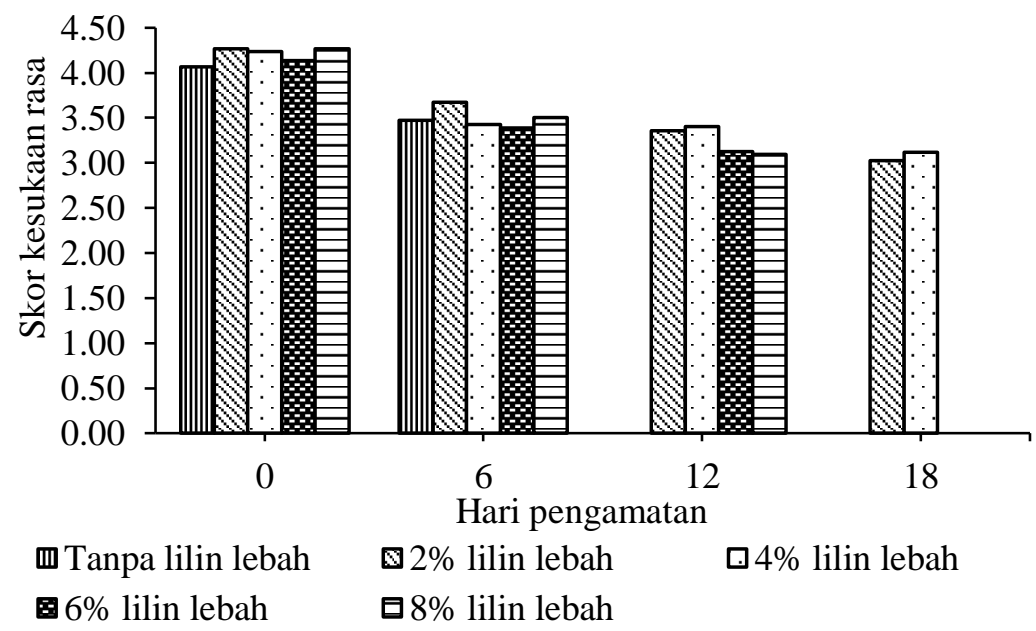

Gambar 5. Perubahan skor kesukaan rasa buah jambu 'Kristal' pada beberapa perlakuan pelilinan 


\section{KESIMPULAN}

Pelapis lilin 2\% dan 4\% mampu menekan susut bobot dan kelunakan buah serta memperpanjang masa simpan buah jambu 'Kristal' hingga 18 hari, dibandingkan dengan kontrol yang hanya mampu sampai dengan 9 hari. Perlakuan pelapisan lilin lebah tidak berpengaruh nyata terhadap kandungan PTT, ATT dan vitamin $\mathrm{C}$ buah.

\section{UCAPAN TERIMA KASIH}

Penelitian ini terlaksana atas pembiayaan Kemenristekdikti melalui Hibah Penelitian Strategis Nasional atas nama Slamet Susanto tahun 2016-2017.

\section{DAFTAR PUSTAKA}

Abdel-Kader, M., N. El-Mougy, S. Lashin. 2011. Evaluation of grapefruit coating with chemical preservatives as control measure against postharvest decay. Pytopathologia. 59: 25-38.

Aji, T.G., S. Susanto, D. Sukma, S.W. Ardie. 2017. Improvement of shelflife and sensory quality of pummelos fruit by waxing and wrapping. J. Tropical Crop Sci. 4(1): 13-20.

[AOAC] Association Official Agriculture Chemist. 1995. Official Method of Analysis of Association Official Agriculture Chemist. Washington DC (US).

Boonyakiat, D., P. Seehanam, N. Rattanapanone. 2012. Effect of fruit size and coating material on quality of tangerine fruit cv. Sai Nam Phueng. Chiang Mai Univ. J. Nat. Sci. 11: 213 230.

[BPS] Badan Pusat Statistik. 2018. Produksi buah jambu biji seluruh provinsi (2016). http://bps.go.id/menutab.php?tabel=1\& kat $=3 \&$ id_subyek $=55 \&$ notab $=0$. [23 April 2018].
Burdurlu, H.S., N. Koca, F. Karadeniz. 2006. Degradation of vitamin $\mathrm{C}$ in citrus juice concentrates during storage. J. Food Eng. 74: 211-216.

Dhyan, S.C., S.H. Sumarlan, B. Susilo. 2014. Pengaruh pelapisan lilin lebah dan suhu penyimpanan terhadap kualitas buah jambu biji (Psidium guajava L.). J. Bioproses Komoditas Tropis. 2(1): 79-90.

[Ditbenih] Direktorat Perbenihan Hortikultura. 2012. Deskripsi jambu biji varietas Kristal. http://varietas.net/dbvarietas/ deskripsi/3136.pdf. [30 Agustus 2016].

Fikrinda, W., S. Susanto, D. Efendi, M. Melati. 2015. Study on fruit quality of selected Seeded pummelo cultivars and its relationship with antioxidant activity content during storage period. Agrivita. 37(3): 210-219.

Fitria, L. 2016. Kajian pertumbuhan, produksi dan kualitas jambu biji (Psidium guajava L.) var. Kristal pada asal bibit dan pemangkasan yang berbeda. [Tesis]. Institut Pertanian Bogor. Bogor.

Hassan, Z.H., S. Lesmayati, R. Qomariah, A. Hasbianto. 2014. Effects of wax coating applications and storage temperatures on the quality of tangerine citrus (Citrus reticulata) var. Siam Banjar. IFRJ. 21(2): 641-648.

[Kementan] Kementerian Pertanian. 2018. Konsumsi komoditas buah-buahan per kapita dalam rumah tangga setahun menurut hasil susenas 2017. https:// aplikasi2.pertanian.go.id/konsumsi/tampil _susenas_kom2_th.php. [23 April 2018].

Li, X.., X. Zhu, H. Wang, X. Lin, H. Lin, W. Chen. 2018. Postharvest application of wax controls pineapple fruit ripening and improves fruit quality. Postharvest Biol. and Tech. 136: 99-110.

Machado, F.L.C., J.M.C. Costa, E.N. Batista. 2012. Application of carnauba-based wax maintains postharvest quality of "Ortanique" tangor. Cienc Tech. Aliment. 32(2): 261-266. 
Mendieta, B., J.A. Olaeta, R. Pedreschi, P. Undurraga. 2017. Reduction of cold damage during cold storage of Hass avocado by a combined use of preconditioning and waxing. Scientia Hort. 200: 119-124.

Pascall, M.A., S.J. Lin. 2013. The application of edible polymeric films and coatings in the food industry. J. Food Process Tech. 4(2): 1-2.

Paull, R.E., O. Duarte. 2012. Tropical Fruits $2^{\text {nd }}$ ed, Volume II. Hulbert S, editor. London (GB): MPG Books Ltd.

Pavlath, A.E., W. Orts. 2009. Edible Films and Coatings: Why, What, and How? In: Huber, K., M. Embuscado (eds.) Edible Films and Coatings for Food Applications. Springer, New York.

Piga, A., S. D'Aquino, M. Agabbio, L. Piergiovanni. 1997. Polyethylene film packaging affects quality of "Lisbon" lemons during long-term storage. Ital. J. Food Sci. 1(9): 25-35.

Rodov, V., T. Agar, J. Peretz, B. Nafussi, J.J. Kim, S. Ben-Yehoshua. 2000. Effect of combined application of heat treatments and plastic packaging on keeping quality of "Oroblanco" fruit (Citrus grandis L. $\mathrm{x} C$. paradisi Macf.). Postharvest Biol. and Tech. 20: 287-294.

Shahid, M.N., N.A. Abbasi. 2011. Effect of bee wax coatings on physiological changes in fruits of sweet orange cv. "Blood Red". Sarhad J. Agric. 27(3): 385-394.

Shetty, M.J., P.R. Geethalekshmi, C. Mini, R. Beena. 2018. Relationship of waxing treatments to certain physiological, browning and sensory characteristics of rambutan (Nephelium lappaceum L.). Int. J. Pure App. Biosci. 6(1): 265-271.

Sirisomboon, P., R. Lapchareonsuk. 2012. Evaluation of the physicochemical and textural properties of pomelo fruit following storage. Fruits. 67: 399-413.

Taris, M.L., W.D. Widodo, K. Suketi. 2015. Kriteria kemasakan buah pepaya (Carica papaya (L.) IPB Callina dari beberapa umur panen. J. Hort. Indonesia. 6(3):172-176.

Vicente, A.R., M. Saladie, J.K.C. Rose, J.M. Labavitch. 2007. The linkage between cell wall metabolism and fruit softening: looking to the future. J. Sci. Food Agric. 87: 1435-1448.

Vázquez-Celestino, D., H. Ramos-Sotelo, D. M. Rivera-Pastrana, M. E. VázquezBarrios, E. M. Mercado-Silva. 2016. Effects of waxing, microperforated polyethylene bag, 1-methylcyclopropene and nitric oxide on firmness and shrivel and weight loss of 'Manila' mango fruit during ripening. Postharvest Biol. and Tech. 111: 398-405.

Widodo, S.E., Zulferiyenni, I. Maretha. 2012. Pengaruh penambahan Indole Acetic Acid (IAA) pada pelapis kitosan terhadap mutu dan masa simpan buah jambu biji (Psidium guajava L.) 'Crystal'. J. Agrotropika. 17(1): 14-18.

Wills, R., B. McGlasson, D. Graham, D. Joyce. 2007. Postharvest: An Introduction to the Physiology and Handling of Fruit, Vegetables and Ornamentals $\left(2^{\text {nd }}\right.$ ed). Sydney $(A U)$ : University of New South Wales. 